\title{
Financial Performance And Compliance With Basel III Capital Standards: Conventional vs. Islamic Banks
}

\author{
Osama M. Al-Hares, Gulf University for Science and Technology (GUST) - Kuwait \\ Naser M. AbuGhazaleh, Gulf University for Science and Technology (GUST) - Kuwait \\ Ahmed Mohamed El-Galfy, Gulf University for Science and Technology (GUST) - Kuwait
}

\begin{abstract}
This study is a commentary on the financial performance and quality capital of Islamic versus conventional banks currently operating in the Gulf Cooperation Council (GCC) region. In addition to assessing the financial performance of the full set of banks across various GCC countries, the study is the first to consider the extent to which Islamic vs. conventional GCC banks comply with the new Basel III requirements of raising better quality capital. The study uses bank-level data for 75 (55 conventional and 20 Islamic) banks in Kuwait, United Arab Emirates, Kingdom of Saudi Arabia, Oman, Qatar, and Bahrain. Financial ratios are used to measure and compare Islamic vs. conventional banks' performances, and we employ a comprehensive and the most recent sample of data available in the region, consisting of cross-sections from 2003 to 2011.
\end{abstract}

The results reveal that Islamic banks are, on average, less efficient but more profitable, more liquid, more solvent (less risky), and enjoyed higher internal growth rates than conventional banks during 2003-2011. The results indicate that there are statistically significant differences between the two types of banks, as far as profitability, solvency, and internal growth rate ratios are concerned; however, there are no statistically significant differences in liquidity and efficiency. The results also indicate that banks, as a whole, appear to be largely sufficiently capitalized for Basel III. Gulf Cooperation Council banks are well positioned to absorb higher provisions and impairment charges given the higher capital adequacy ratios reported by most. The Common Equity Ratio, Tier 1 Capital Ratio, and Capital Adequacy Ratios (CARs), for the majority of banks in 2011, comfortably satisfy the enhanced capital requirements of Basel III. The results show that Islamic banks have, on average, noticeably higher (and significantly different) capital ratios compared to conventional institutions. With regard to the impact of the global financial crisis on both types of the banks, the results indicate that Islamic banks performed better than conventional banks during the period 2006-2009, as the former enjoys higher capitalization, higher liquidity reserves, and also maintained stronger growth compared to conventional banks in almost countries.

Findings of this study may be useful for capital-market participants, as the full set of banks across various Gulf Cooperation Council countries needs to be examined before any substantive conclusions can be reached about the relative performance of Islamic versus conventional banks. Further, as the full implementation of Basel III requirements will not take place until 2019, the results of this study will convey information that should encourage banks to consider the earlier implementation of Basel III capital requirements in order to provide themselves with a reputational boost, as well as a competitive advantage.

Keywords: Gulf Cooperation Council (GCC), Islamic Banks, Conventional Banks, Basel III Capital Standards

\section{INTRODUCTION}

Slamic finance has emerged in recent decades as an interesting trend in the financial world. There has
always been a demand among Muslims for financial products and services that conform to Shariah,
which, in turn, is based on the Qur'an and Sunnah. Muslims have tried to develop viable Islamic
alternatives to conventional finance in order to have Shariah-compliant solutions to their financial needs. The most 
distinctive elements that define the nature and scope of Islamic finance as interpreted by Shariah scholars are the prohibition of interest "usury", whether "nominal" or "excessive", simple or compound, fixed or floating; the emphasis on equitable contracts; the prohibition of uncertainty; the existence of an underlying asset; the linking of finance to productivity; risk sharing; the desirability of profit sharing; and the prohibition of unethical investments.

There has been much questioning of the effect of the financial crisis on Islamic companies, especially banks, compared to conventional institutions, and it has been strongly argued that if worldwide financial practices had adhered to the principles of Islamic finance, which are based on noble ideas of entrepreneurship and transparency, then such a global predicament would have been prevented. This argument is built simply on the fact that most, if not all, the factors that have caused or contributed to the development and spread of the current global financial crisis are not allowed under the rules and guidance of Islamic finance.

Islamic finance has remained relatively positive, resilient, and largely shielded from the crisis despite the gloom and volatility of the prevailing global financial environment (Hamdan, 2009) - growth rates of $28 \%$ verify the popularity of this approach to money management very ably. Wilson (2009) argues that the recent financial crisis facing conventional banking has directed attention to the Islamic banking sector, where banks which emphasize transparency and undue risk avoidance have been largely insulated from the crisis.

This study examines the financial performance of the banking industry in the GCC region using Financial Ratio Analysis (FRA) in terms of profitability, liquidity, efficiency, solvency, and growth. The study is motivated by the fact that the competition between Islamic and conventional banks has recently increased in light of the recent economic travails, increasing globalization, and the growing attraction of Islamic finance worldwide. This study starts by evaluating the differences in financial performance between conventional and Islamic banks. The analysis then proceeds to assess the extent to which Islamic vs. conventional banks in the GCC region comply with the new Basel III requirements for higher and better quality capital that can be used in periods of financial stress. Basel III's new liquidity standards do not lie within the scope of our study.

The choice of the GCC zone is justified by the fact that these countries, which are the heart of the Islamic world, are experiencing a significant increase in numbers of banks, a high growth rate of Shariah-compliant global financial assets, and sound financial health. Islamic financial institutions in the GCC region are taking an increasingly global perspective (i.e. expanding in countries outside the GCC region, mainly Malaysia, Singapore, Turkey, and Australia, through a large number of subsidiaries and branches) and are more innovative than in other countries where Islamic banks enjoy a monopoly of banking services in terms of products and development (e.g. Iran). Wilson (2009) argues that Islamic banks in the GCC region offer a much more diversified and attractive range of services, perhaps because of the need to compete with conventional banks in their local markets. He indicates that Sharia-compliant banking assets in the GCC are seeing exceptional 30\%-plus growth rates and currently account for two-thirds of global Islamic assets. He also points out that "the value of Shariah-compliant assets is impressive in the GCC. The current size of the global Islamic finance industry is at over \$1 trillion, with GCC having \$262.6 billion". According to Ernst \& Young's World Islamic Banking Competitiveness Report 2011, the Islamic banking market share of all banking assets in the MENA region has reached 14\%, while within the GCC, Islamic banks now account for just over a quarter of all banking assets. Outside Iran, which is a fully compliant market, Saudi Arabia and Malaysia have the largest Islamic banking markets by assets.

Our analysis is based on bank-level data for 75 (55 conventional and 20 Islamic) banks in Kuwait, United Arab Emirates, Kingdom of Saudi Arabia, Oman, Qatar, and Bahrain. We employ a comprehensive and the most recent sample of data available in the GCC, consisting of cross-sections from 2003 to 2011. In addition, and to our best knowledge, this study is the first to assess the extent to which Islamic vs. conventional banks in the GCC comply with the new Basel III capital requirements. The full implementation of Basel III requirements will not take place until 2019; hence, we argue that the results of this study will convey information that will encourage GCC banks to consider earlier implementation in order to provide themselves with a reputational boost, as well as a competitive advantage. Furthermore, depending on how far away GCC banks are from meeting the new capital standards, the results of this study could cause major changes in the ways they do business, from internal modeling to priorities in the acquisition and disposal of assets. 
The main purpose of this study is to assess the financial performance of Islamic vs. conventional banks in the GCC region by using ratio analysis, and to answer the question as to which banking system complies better with Basel III's new requirements for higher and better quality capital. The next section highlights the main features of Islamic banking and underlines Islamic banks history, while Section 3 presents Basel III's new capital standards. Section 4 reviews relevant prior research and Section 5 describes the methodology and model specifications. Finally, Section 6 reports the results and Section 7 concludes.

\section{BACKGROUND ON ISLAMIC BANKS}

The most distinctive elements of "Islamic finance" in general and "Islamic banking" in particular can be summarized as: (i) The prohibition of interest "USURY" whereby banks are not allowed to receive or pay interest; (ii) the linking of finance to productivity whereby money must be used in a productive way and wealth can only be generated through legitimate trade and investment in assets; (iii) freedom from Al Gharar whereby all forms of contracts and transactions must be free from excessive uncertainty; (iv) freedom from Darar whereby contracts should not be harmful to any party; (v) freedom from impulse whereby investors are prevented from making mistakes that are harmful to their interests (e.g. investors may be provided a specific period during which they can cancel an impulsive transaction); (vi) an emphasis on equitable contracts whereby investors have the right not to be forced into a transaction, not to be prevented from entering into a transaction, have equal access to particular information, and have the right to enjoy equal power in negotiations leading to a transaction; (vii) the desirability of profit sharing whereby gains are shared between the party providing the capital and the party providing the expertise; (viii) the prohibition of unethical investments, such as alcohol, gambling, tobacco, pork products, nonIslamic hotels or resorts, sensual entertainment, etc.; and (ix) the prohibition of investment in conventional bonds. Islamic banks play roles similar to conventional banks, but fundamental differences exist between the two models. Conventional banking, for instance, allows for risk transfer and is mainly a debt-based practice centered on the debtor-creditor relationship between the depositors and the bank on the one hand and between the borrowers and the bank on the other. They make their profits from the margin between borrowing and lending rates of interest. Interest is considered the price of credit, reflecting the opportunity cost of money. Under the conventional banking model money is used as a commodity which is bought and sold, and on such two-way transactions they charge interest on it and make profits. In contrast, Islamic banking is asset-based and centers on risk sharing. Moreover, the money is used as a vehicle of exchange to facilitate trade transactions.

Theoretical Islamic economics discussions led to the first modern experiment with Islamic banking in Egypt, which began in 1963 in Mit-Ghamr, a town about 80 kilometers from Cairo. This pioneering experiment took the form of a saving bank based on profit sharing rather than a commercial bank. It lasted until 1967, by which time there were nine such banks operating throughout the country, with more than 250,000 depositors. The banks which neither received nor paid any interest invested mostly by engaging in trade and industry, directly or in partnership with others, and shared the profits with their depositors. The banks were functioning essentially as savinginvestment institutions rather than as commercial institutions (Siddique, 1986; Ariff, 1988; Al-Omar and AbdelHaq, 1996; Taylor, 2003).

In the 1970s, the Islamic banking movement reemerged with the establishment by the Organization of Islamic Countries (OIC) of the Islamic Development Bank (IDB) in 1974, which has since been considered as the kick-starter for the movement's second phase (Abdel-Haq, 1989). Many Islamic banks were not only established in Muslim countries, but also gained footing in non-Muslim countries. Dubai Islamic Bank (1975), Faisal Islamic Bank of Egypt (1977), Faisal Islamic Bank of Sudan (1977), and Bahrain Islamic Bank (1979) were amongst the earliest commercial banks in Arab countries, while the Islamic Finance House was established in Luxembourg in 1978 to represent the first attempt at Islamic banking in the Western world. To date, 20 Islamic financial institutions in the USA and 50 institutions in Europe have adopted the Islamic financial trend; 30 of the latter currently operate in the UK.

Islamic financial institutions take the form of commercial banks, investment banks, investment and finance companies, insurance companies, and financial service companies. They follow different banking models, such as private institutions in a conventional economy (as in most Arab countries and the West), national Islamic banking systems (as in Sudan and Iran), and dual banking models (as in Malaysia). They also take different forms such as 
wholly Islamic institutions, Islamic subsidiaries of conventional banking groups, and Islamic banking windows within conventional banks.

Given a total population of some 1.5 billion Muslims worldwide, Islamic finance in general and Islamic banking in particular represent serious business for Muslims. Islamic finance is one of the world's fastest-growing economic sectors within a global financial services industry that comprises more than 400 institutions. Shariahcompliant financial assets have been growing at over $20 \%$ of sustained annual growth for the past several years. Measured by the Shariah-compliant assets of financial institutions, the global Islamic finance industry achieved a critical volume estimated in excess of US\$ 1 trillion (US\$1,000 billion) by 2010.

Central to Islamic finance is the fact that money itself has no intrinsic value. As a matter of faith, a Muslim cannot lend money to or receive money from someone and expect to benefit, which means that interest (known as 'Riba' in Islam) is not allowed and making money from money is forbidden. Money must therefore be used in a productive way, by which wealth can only be generated through legitimate trade and investment in assets. The principal means of Islamic finance are based on trading, and any trading gains are shared between the party providing the capital and the party providing the expertise. As a result, Islamic banks have developed four main financing techniques, namely Mudaraba, Musharaka, Ijara, and Murabaha (Chapra, 1998; Haron, 2000; Schaik, 2001; Alam, 2003; Accounting and Auditing Organization for Islamic Financial Institution "AAOIFI", 2010).

Mudaraba (trust financing) is a partnership between a financing partner and a managing partner. The financing partner (the financier) entrusts his capital to the managing partner (entrepreneur), who in turn contributes his knowledge and entrepreneurial skills to the project. The financing partner is not involved in the actual management of the partnership, which makes this approach the preferred form of partnership for banks. Profits are shared using a predetermined ratio; however, in the event of a loss the financing partner bears the loss, while the managing partner loses his effort and time, unless this loss was caused by the irresponsible behavior of the managing partner (Chapra, 1998; Schaik, 2001; “AAOIFI", 2010). In this sense, Islamic banks themselves are regarded in the Islamic Fiqh as Mudaraba companies, where depositors are regarded as the financier and the bank's management is regarded as the entrepreneur.

Musharaka (joint venture, or profit and loss-sharing "PLS") means a profit and loss-sharing joint venture, which is intended to combine the talents of two or more partners in a business enterprise, where each of them contributes capital, managerial expertise, effort, and other essential services in equal or varying degrees. Accordingly, they share in both risks and financial results on the basis of their share of capital and effort. Since most banks do not wish to be actively involved with the management of a venture, this form of partnership is not commonly applied in Islamic institutions (Schaik, 2001; Alam, 2003; AAOIFI, 2010).

Ijarah is simply an Islamic lease agreement. It is defined by AAOIFI (2010) as "Ownership of the right to the benefit of using an asset in return for consideration" (AAOIFI, 2010, p. 258). In this type of financing, the bank purchases a piece of equipment selected by a client and then leases it back to him/her for a specified rental amount over a specific period. The duration of the lease and the basis for rental are set and agreed in advance (Pomeranz, 1997). In some cases, the bank may lease a tangible asset from a third party and sublease it to its client (Ali, 2004). Islamic banks are currently practicing this technique in circumstances under which clients eventually choose to buy the item(s). In such circumstances, Ijarah is practiced, either in the form of "Ijarah-wa-Iktena" or "Ijarah with diminishing Musharaka". A "Ijarah-wa-Iktena" contract extends the concept of Ijarah to a hire-and-purchase agreement and includes a promise from the client to buy the equipment at the end of the lease period at a pre-agreed price. Rentals paid during the period of the lease constitute part of the purchase price. In other words, the monthly payment will consist of two components: Rental for the use of the equipment and an instalment towards the purchase price. Often, as a result, the final sale will be for a token sum. However, the "Ijarah with diminishing Musharaka" contract is widely used for home-buying services. Diminishing Musharaka means that the bank reduces its equity in an asset with any additional capital payment the client makes over and above his/her rental payments. Consequently, the client's ownership in the asset increases and the bank's ownership decreases by a similar amount each time the client makes an additional capital payment. Ultimately, the bank transfers ownership of the asset entirely over to the client. The liquidity risk in both types of Ijara contract will therefore be limited, as the sale price is built into the rental instalments (Suleiman, 2000). 
Murabaha (mark-up financing, or cost-plus financing) is defined in the Islamic Fiqh as the sale of goods at cost plus an agreed profit mark-up (Al-Gzaairi, 1979; Al-Jinde, 1986; AAOIFI, 2010). It is very important in this type of financing that the seller truthfully informs the purchaser of the price at which he purchased the product and stipulates an amount of profit in addition to this price. Thus, Murabaha is, in theory, a form of trade financingsimply a sales contract that fixes the price of certain goods or items plus a specified percentage mark-up (profit). However, it is currently practiced as an agreement between a final buyer (the customer) and a middleman (the Islamic bank), by which the Islamic bank plays the role of financer. In this case, a client requests the bank to purchase the selected goods according to certain specifications. Once the bank purchases the goods, it resells them to that client at the cost price plus a certain amount of profit. The Murabaha contract in such a case is called "Murabaha to the Purchase Orderer" (Al-Qaradawi, 1987; Shehatah, 1987; El-Galfy, 1991; Suleiman, 2000).

\section{BASEL III CAPITAL STANDARDS}

The Basel III Committee of Banking Supervision announced its endorsement of Basel III regulations and requirements that build on the existing regulatory structures of the Basel I and Basel II accords. The regulators' intent in instigating Basel III is a future of more capital, more liquidity, and lower risk, which improves the ability of the banking sector to absorb financial and economic shocks, improves risk management and governance, and strengthens banks' transparency and disclosures. Basel III establishes higher and better quality capital standards through additional capital buffers, more restrictive capital definitions, higher risk-weighted assets (RWSs), and higher requirements for minimum capital ratios. Higher capital requirements primarily allow banks to use capital accumulated during boom times in periods of financial stress and hence reduce cyclicality in financial markets. In addition, Basel III establishes liquidity standards through the introduction of liquidity coverage and net stable funding ratio targets, although these new liquidity standards beyond the scope of our study.

The implications of increased capital requirements include significant effects across the banking industry and capital markets. The reforms will fundamentally reduce industry profitability (as measured by ROE) and require the alteration of balance sheet management techniques to limit illiquid assets, restrict unstable sources of funding, and manage higher funding costs. These reforms will also require banks to transform their business models (e.g. due to higher capital costs) and to undertake significant process and system changes to achieve upgrades in areas of stress testing, counterparty risk, and capital management infrastructure.

Table 1 represents the Basel III capital standards required to be met by January 2019. The Committee's package of reforms will increase the Minimum Common Equity requirement to $4.5 \%$. Minimum Common Equity is also known as the Tangible Common Equity Ratio and basically consists of common shares plus retained income. The ratio is calculated by taking the value of the company's total equity and subtracting intangible assets, goodwill, and preferred stock equity, and then dividing this figure by the value of the company's tangible assets. In addition, banks will be required to hold a capital conservation buffer of $2.5 \%$ to withstand future periods of stress, thus bringing total common equity requirements to $7 \%$ in total.

Tier 1 capital is one of the most prominent risk measures employed to determine bank capital adequacy. The ratio itself is important, as it gives an insight into the losses a bank can take before solvency becomes a serious concern. It is the core capital which includes common equity as can be found on the balance sheet including other qualifying financial instruments based on stricter criteria (share premiums, retained profit, general reserves and legal reserves), but it may also include non-redeemable, non-cumulative preferred stock. The Basel Committee also observed that banks have used innovative instruments over the years to generate Tier 1 capital; these are subject to stringent conditions and are limited to a maximum of $15 \%$ of total Tier 1 capital. The Tier 1 capital requirement will increase to 6\%, which means that other types of Tier 1 instruments can account for up to $1.5 \%$ of Tier 1 capital.

Total Capital to Risk Weighted Assets Ratio (CRAR), also known as the Capital Adequacy Ratio (CAR) determines the capacity of a bank in terms of meeting time liabilities and other risks such as market risk, operational risk, credit risk, and other threats. Essentially, it is a measure of how much capital is used to support a bank's risk assets and is used to protect depositors and promote the stability and efficiency of financial systems around the world. CAR is a measure of a bank's total capital that measures in addition to Tier 1 capital, secondary bank capital known as Tier 2 capital, which includes items such as undisclosed reserves, general loss reserves, subordinated debt, hybrid debt, and equity instruments. Tier 2 capital ratio itself provides an insight into the losses a bank can absorb in the event of winding-up and so provides a lesser degree of protection to depositors. 
The Group of Governors and Heads of Supervision also agreed that the capital conservation buffer above the regulatory minimum requirement should be calibrated at $2.5 \%$ and be met with common equity (after the application of deductions). A countercyclical buffer within a range of $0 \%-2.5 \%$ of common equity (or other fully loss-absorbing capital) will be implemented according to national circumstances. The purpose of the countercyclical buffer is to achieve the broader macro-prudential goal of protecting the banking sector from periods of excess aggregate credit growth. For any given country, this buffer will only come into effect when there is excess credit growth resulting in a system-wide build-up of risk. The countercyclical buffer, when in effect, would be introduced as an extension of the conservation buffer range. As of 1 January 2019, banks will be required to meet the following new minimum requirements in relation to risk-weighted assets (RWAs): $4.5 \%$ common equity/RWAs, $6.0 \%$ Tier 1 capital/RWAs, and $8.0 \%$ total capital/RWAs Finally, the difference between the total capital requirement of $8.0 \%$ and the Tier 1 requirement can be met with Tier 2 and higher forms of capital.

Table 1

Basel III Capital Standards by January 2019

(All numbers in relation to Risk-Weighted Assets (RWAs))

\begin{tabular}{|l|c|c|c|}
\hline & $\begin{array}{c}\text { Common Equity } \\
\text { (After Deductions) }\end{array}$ & Tier 1 Capital Ratio & Total Capital \\
\hline Minimum & $4.5 \%$ & $6.0 \%$ & $8.0 \%$ \\
\hline
\end{tabular}

\begin{tabular}{|ll} 
Capital Conservation Buffer & $2.5 \%$ \\
\hline
\end{tabular}

\begin{tabular}{|l|c|c|c|}
\hline Minimum Plus Capital Conservation Buffer & $\mathbf{7 . 0 \%}$ & $\mathbf{8 . 5 \%}$ & $\mathbf{1 0 . 5 \%}$ \\
\hline Counter-Cyclical Buffer & $0-2.5 \%$ & & \\
\hline Maximum & & & $\mathbf{1 3 . 0 \%}$ \\
\hline
\end{tabular}

\section{LITERATURE REVIEW}

The literature review starts by explaining general Islamic financial principles to the non-Muslim reader (e.g. Bashier, 1983; Khan, 1986). Later, claims are raised by researchers as to whether Islamic banks are the answer to any economic crisis, and studies in this vein focus on whether Islamic banking practices are better off in terms of performance, financial position, and risk level than conventional banking practices during economic crises. Most studies support that Islamic banking practices are more stable than conventional banking as there is less fluctuation in rates of returns, inflation, and other economic considerations (e.g. Karim and Ali, 1989; Turen, 1996; Cihak and Hesse, 2010). Karim and Ali (1989) investigate the effect of the interaction between environment (competition) and financial strategies adopted by banks on the capital structure of two Islamic banks, Faisal Islamic Bank and Kuwait Finance House, during 1979-1985. They indicate that the composition of the capital structure of the two banks examined is dependent upon management's strategic choices, and they suggest that Islamic banks may prefer to obtain funds from depositors rather than from shareholders during expansionary periods in an economy. When combined with the requirement for risk sharing, return on equity should be higher for Islamic than for conventional banks. Turen (1996) investigates quantitatively and at the micro level the claim that Islamic banking offers higher performance and stability than conventional banking. The analysis is conducted for both Bahrain Islamic Bank and the remaining locally incorporated commercial banks in Bahrain and is conducted by using three different methods. First, for the years 1979-1989, various profitability ratios and their risk levels (standard deviation and coefficient of variation) are calculated for Bahrain Islamic Bank and for the commercial banking sector as a whole in Bahrain. Second, for the years 1986-1990, rates of return for Bahrain Islamic Bank's common stock and their standard deviations are compared with other common stocks listed on the Bahrain Stock Market. Third, the behavior of Bahrain Islamic Bank's stock is investigated across five-stock portfolios in order to determine any patterns in risk diversification characteristics. The results reveal that Bahrain Islamic Bank offers higher profitability and lower risk than the commercial banks. The results also indicate that Bahrain Islamic Bank offers a higher rate of return and lower risk than available in the commercial banking sector. Furthermore, the results show that the least risky portfolio out of the total of 2,268 possible five-stock portfolios contains, with four other industry stocks, only Bahrain Islamic Bank's stock as the commercial banking sector stock. Moreover, while Bahrain Islamic Bank's stock is present in 17 portfolios of the 30 least risky portfolios, none of the other commercial bank stocks is part of these portfolios. Turen (1996) argues that conventional bankers may achieve an above average performance at a 
moderate risk level by using the techniques of Islamic banks. Cihak and Hesse (2010) provide a cross-country empirical analysis of the role of Islamic banks in financial stability. Their sample covers banks in Bahrain, Bangladesh, Brunei, Egypt, Gambia, Indonesia, Iran, Jordan, Kuwait, Lebanon, Malaysia, Mauritania, Pakistan, Qatar, Saudi Arabia, Sudan, Tunisia, United Arab Emirates, West Bank and Gaza, and Yemen. In total, they make up to 520 observations of 77 Islamic banks (and 3,248 observations of 397 commercial banks) over the period 1993 to 2004. Cihak and Hesse empirically assess the relative financial strength of Islamic banks. The results indicate that small Islamic banks tend to be financially stronger than small commercial banks, while large commercial banks tend to be financially stronger than large Islamic banks. The results also reveal that Islamic banks, while relatively more stable when operating on a small scale, are less stable when operating on a large scale, which may reflect the challenges of credit risk management in large Islamic banks and more concentration on low-risk investments and fee income in smaller banks. Cihak and Hesse (2010) also find that the market share of Islamic banks does not have a significant impact on the financial strength of other banks.

The literature on assessing the performance of the banking sector uses various indexes and concentrates on measuring and comparing the performances of different banks across countries and over time; these are usually known as efficiency studies. One line of research in this area uses mainly the non-parametric Data Envelopment Analysis (DEA) approach (e.g. Bashir, 2003; Yudistira, 2004; Ramanathan, 2007), which is used to examine how a particular bank operates relative to other banks in the sample, and then specify best practice (i.e. the best level of output from the given inputs of other banks in the sample). Bashir (2003), using cross-country, bank-level data from 14 Islamic banks in eight Middle East countries during 1993-1998, examines the determinants of Islamic banks' performance (i.e. profitability). He uses regression analysis among a variety of internal and external banking characteristics after controlling for economic and financial structure indicators. The results indicate that Islamic banks' profitability measures respond positively to increases in capital and loan ratios, and loan portfolios play an empirical role in explaining their performance. The results also show that profitability is mostly generated from short-term customer funding, non-interest earnings assets, and overheads. Bashir (2003) further argues that since deposits in Islamic banks are treated as shares, reserves do not yield any return and holding reserves reduces the funds available for investment. Yudistira (2004) uses panel data from 18 Islamic banks from 12 countries (i.e. four GCC, two East-Asian, three African, and three other Middle-Eastern countries) and controls for size and region over the period 1997-2000. The overall efficiency results show that inefficiency across 18 Islamic banks is small (at just over $10 \%$ ), which is considerable compared to many conventional counterparts. The results also reveal that Islamic banks suffered from slight inefficiencies during the 1998-1999 global crisis but performed very well after this difficult period. His results also show that efficiency differences are determined by country-specific factors, and Islamic banks outside the Middle-Eastern region are more efficient than their counterparts in the region. Yudistira (2004) argues that market power does not have a significant impact on Islamic banks' efficiency in the Middle East, as those from outside the region are relatively new and greatly supported by their regulators. Ramanathan (2007) assesses the performance of 55 banks operating in the GCC region over the period 2000-2004. The results indicate that only 15 banks of the 55 banks are rated as efficient.

Among the many different tools and techniques used as performance measures, financial ratios are used quite commonly and extensively in the literature. One stream of research using financial ratios has focused on the profitability of the banking sector in general, without any comparison between Islamic and conventional institutions, in one or more countries in the Islamic world (e.g. Ahmed and Khababa, 1999; Islam, 2003; Essayyad and Madani, 2003; Tamimi and Al-Amiri, 2003).

Ahmed and Khababa (1999) study the effect of business risk, market concentration, and size on the profitability of 11 commercial banks in Saudi Arabia for the period 1992-1997. The authors employ a regression model using three measures of profitability: Return on assets, return on equity, and earnings per share, and their results show that business risk and size explain bank profitability in Saudi Arabia. Islam (2003) investigates the development and performance of commercial banks in Bahrain, Oman, Dubai, and Abu Dhabi in the United Arab Emirates for the period 1998-2000. He uses several financial ratios to measure bank performance and shows that GCC banks perform well relative to their Western counterparts. He also indicates that competition among GCC banks increased over the period examined. Essayyad and Madani (2003) examine the concentration, efficiency, and profitability of 10 commercial banks in Saudi Arabia for the period 1989-2001. Their results indicate that the Saudi Arabian banking industry is highly concentrated and has a four-firm concentration ratio ranging between $69 \%$ and 
$87 \%$. They also show that profitability rises with increases in bank efficiency and that bank profits are positively related to oil revenues. Finally, Al-Tamimi and Al-Amiri (2003) examine the service quality of two Islamic banks in UAE (Abu Dhabi Islamic Bank and Dubai Islamic Bank) by distributing questionnaires to 700 customers. About 350 responses are received and they reveal that customers are very satisfied with the quality of services received from these banks.

Other streams of research have used financial ratios to measure and compare Islamic and conventional banks' performances (e.g. Karim and Ali, 1989; Rosly and Abu Baker, 2003; Olson and Zoubi, 2008; Kader and Asarpota, 2007; Moin, 2008; Parashar and Venkatesh, 2010; Hasan and Dridi, 2010; and Beck et al., 2010). Olson and Zoubi (2008) investigate whether financial ratios will differ significantly between the two categories of banks by examining 16 financial ratios commonly used in the banking industry and using logit, neural networks, and kmeans nearest neighbors to determine whether researchers or regulators could use these ratios to distinguish between types of banks. Although the two categories have similar financial ratios, the best nonlinear classification technique (k-means nearest neighbors) is able to distinguish correctly between the two types in out-of-sample tests at about an $87 \%$ success rate. The results reveal that characteristics such as profitability ratios, efficiency ratios, asset quality indicators, and cash/liability ratios are good discriminators in the GCC region. They also indicate that Islamic banks are, on average, more profitable than conventional banks but less efficient, and they go on to argue that accounting numbers are useful for classifying firms within the same industry into two or more categories based on financial characteristics.

Karim and Ali (1989) examine the financial ratios of GCC Islamic banks and suggest that they are more profitable than other GCC banks. Rosly and Abu Baker (2003) examine six financial ratios for Islamic and mainstream banks in Malaysia for the years 1996-1999. They show that Islamic banks' returns on assets, profit margins, and net operating margins are statistically larger than for conventional banks, while liquidity, operating efficiency, and asset utilization ratios are statistically smaller. Nevertheless, they suggest that Islamic banks have chosen to behave more like mainstream banks than required by Shariah principles. Their research leaves unresolved the question as to whether both types of banks behave similarly in other countries and whether financial ratios can be used to distinguish meaningfully between the two counterparts. Kader and Asarpota (2007) utilize bank-level data to evaluate the performance of Islamic versus conventional banks in the United Arab Emirates (UAE) during the period 2000-2004. Financial ratios are used to examine performances in profitability, liquidity, risk and solvency, and efficiency. The results indicate that Islamic banks are relatively more profitable, less liquid, less risky, and more efficient. Moin (2008) examines the performance of the first Islamic bank in Pakistan, Meezan Bank Limited (MBL), in comparison with a group of five conventional Pakistani banks with respect to profitability, liquidity, risk, and efficiency for the period of 2003-2007. He uses 12 financial ratios, including the return on asset (ROA), return on equity (ROE), loan to deposit (LDR), loan to assets (LAR), debt to equity (DER), asset utilization (AU), and income to expense (IER) ratios to assess banking performances. T-tests and F-tests are used to determine the significance of the different performances of the two groups of banks. His results reveal that MBL is less profitable, more solvent (less risky), and less efficient compared to the average of the five conventional banks. However, Moin (2008) points that Islamic banks improve and perform far better over time by making good returns on assets, managing their operating expenses, and satisfying their shareholders by offering competitive or even better returns, thus indicating convergence with the performance of conventional banks. In terms of liquidity, the results indicate that there is no significant difference between the two sets of banks.

Parashar and Venkatesh (2010) compare conventional and Islamic bank performance in the GCC before and during the global financial crisis using ratio analysis. The study uses six ratios, namely the return on average assets ratio, the return on average equity ratio, the capital adequacy ratio, the cost to income ratio, the equity to total assets ratio, and the liquid assets to total assets ratio. These ratios are spread across five bank performance parameters, namely capital, efficiency, profitability, liquidity, and leverage. Their study covers the period 2006-2009 using a sample of 12 banks, six Islamic and six conventional. The results indicate that Islamic banks have suffered more than conventional banks during the recent global financial crisis in terms of capital ratio, leverage, and return on average equity, while conventional banks have suffered more in terms of return on average assets and liquidity. The results however reveal that despite the hit in terms of certain ratios during the crisis period, Islamic banks performed better than conventional banks during the four-year period of 2006-2009. 
Hasan and Dridi (2010) examine the performance of Islamic Banks and conventional banks during the recent global financial crisis by examining the impact of the crisis on profitability, credit, and asset growth, as well as external ratings in a group of countries where the two groups of banks have significant market share, including Bahrain, Jordan, Kuwait, Malaysia, Qatar, Saudi Arabia, Turkey, and the UAE. The results reveal that factors related to the Islamic business model helped limit the negative impact on profitability in 2008, while weaknesses in risk management practices in some Islamic banks led to a larger decline in profitability in 2009 compared to conventional banks. The results also indicate that Islamic banks maintained stronger credit and asset growth compared to conventional banks in almost all countries. Furthermore, external rating agencies' reassessment of Islamic banks' risk was generally more favorable. Hasan and Dridi (2010) argue that strong credit and asset growth suggests that the market share of Islamic banks is likely to continue to increase going forward and that they contribute more to macro stability by making more credit available and are less affected by deleveraging. They also point out that "... the crisis has led to greater recognition of the importance of liquidity risks, and the need for efficient bank resolution framework. Hence, building a well-functioning liquidity management infrastructure is a key priority. Moreover, regulators and standard-setters for Islamic banks should ensure that the supervisory and legal infrastructure, including for bank resolution, remain relevant to the rapidly changing Islamic financial landscape and global developments".

Beck et al. (2010) use bank-level data to construct and compare indicators of the business models, efficiency, asset quality, and stability of conventional and Islamic banks. Their sample consists of over 2,900 institutions in 141 countries, focusing particularly on 20 countries with a mixed banking system (a subset of 486 banks of which 89 are Islamic). They compare the two types of banking and their performance during the 1995-2007 pre-crisis period, and also compare pre- and post-crisis performance using more recent data (2008-2010). The results reveal that both types were affected by the financial crisis. During 2005-2010, Islamic banks had higher capitalization and higher liquidity reserves, and also significantly increased this liquidity, which resulted in better performance. The results also show that Islamic banks are more cost-effective in a large sample of countries; however, conventional banks tend to be more cost-effective than their counterparts in countries where both types of bank exist. Furthermore, Islamic banks are less cost-effective but more stable in countries where the market share of Islamic banks is higher.

A comprehensive sample of data available in the GCC needs to be examined before any substantive conclusions can be reached about the relative performances of Islamic and conventional banks. This study is a commentary on the financial performance and quality capital of Islamic and conventional banks currently operating in the GCC region. In addition to assessing this financial performance using ratio analysis, this study is the first to consider the extent to which these banks comply with the new Basel III requirements to raise better quality capital. We are not aware of any study in the literature which assesses the compliance of the banking industry with Basel III capital standards.

\section{RESEARCH METHODOLOGY}

The study uses bank-level data for 75 (55 conventional and 20 Islamic) banks in the GCC region. We employ comprehensive and the most recent sample of data available in the GCC, consisting of annual cross-sections taken from 2003 to 2011. There are 10 conventional banks in the Kingdom of Bahrain, seven in the State of Kuwait, eight in Sultanate of Oman, six in the State of Qatar, nine in the Kingdom of Saudi Arabia, and 15 in United Arab Emirates. The study also includes 20 Islamic banks operating in the GCC region.

The basic financial data used in this study is obtained from the GCC stock markets' annual guides and corporate fact sheets, in addition to the banks' annual reports available on their websites. It is worth noting that some published annual reports do not contain details adequate enough for comprehensive and in-depth financial analysis. In addition, there is no standard format for all GCC banks. The Bank of Kuwait and Middle East (Kuwait) became an Islamic bank from 1st April, 2010; also, the name was changed to Ahli United Bank. The bank's financial data is classified with the conventional bank data in this study. The notes from the financial statements were examined to determine whether all the banks in our study complied with the International Accounting Standards (IAS) during the period 2003-2011. This requirement was verified as true for every institution in our sample. An individual countrywise analysis is not intended here, and we focus on evaluating bank group indicators as a whole (conventional and 
Islamic). Both Islamic banks and conventional banks are placed on an equal footing under ratio measures, irrespective of the bank's size.

The annual data for all banks is used for calculating key financial ratios in order to assess performance. This study examines the financial performance of the banking industry in the GCC region using financial ratio analysis (FRA) in terms of profitability, liquidity, efficiency, solvency, and growth, and we apply the same criteria used in previous studies to assess these categories (e.g. Demirgue-Kunt and Hizinga, 1999; Samad and Hassan, 2000; Yudistira, 2004; Rosly and Abu Baker, 2003; Essayyad and Madani, 2003; Olson and Zoubi, 2008). The study uses a descriptive financial analysis to describe, measure, and compare the financial situations of all banks. We first calculate the average of each ratio in each group, and then use a T-test to determine the significance of the different performances.

Profitability ratios assess the ability of the bank to generate earnings in comparison with its total expenses, other relevant costs, and income taxes. Profitability ratios are considered to be basic bank financial ratios and are taken as indicators of better bank performance (Ross, Westerfield, and Jaffe, 2005). Our study judges profitability using return on assets (ROA), return on equity (ROE), net interest margin (NIM), and return on deposits (ROD). Previous studies indicate that profitability ratios in general are expected to be higher for Islamic banks (e.g. Karim and Ali, 1989; Rosly and Abu Baker, 2003; Kader and Asarpota, 2007; and Olson and Zoubi, 2008) or improve consistently better than conventional banks over time (e.g. Moin, 2008).

Liquidity ratios indicate the ability of the bank to meet short-term financial obligations on time and hence avoid financial distress (Ross, Westerfield, and Jaffe, 2005). Our study gauges liquidity using the total loans to deposits ratio (LDR), total loans to total assets ratio (LAR), and cash and portfolio investment to deposit ratio (CPIDR). Previous studies present evidence that Islamic and conventional GCC banks have similar liquidity ratios but conventional banks seem to have better liquidity in comparison to Islamic banks (e.g. Rosly and Abu Baker, 2003; and Kader and Asarpota, 2007).

Efficiency ratios measure how effective the bank uses and controls its assets. In other words, these ratios indicate the bank's ability to turn resources into revenue. Ratios used in this respect are the assets utilization (turnover) ratio (AUR), and operating expenses to operating revenues (operating efficiency) ratio (OER). The literature shows that Islamic banks are expected to be less efficient than conventional banks (e.g. Yudistira, 2004; Rosly and Abu Baker, 2003; Abdul-Majid et al., 2005; Drake et al., 2006; Olson and Zoubi, 2008; Moin, 2008).

Solvency ratios also referred to as 'financial leverage' ratios. Financial leverage represents the extent to which a bank relies on debt financing rather than equity. Hence, leverage allows a financial institution to increase potential gains or losses on a position or investment beyond what would be possible through the direct investment of its own funds. It also provides a measurement of how likely a bank will be to continue meeting its long-term debt obligations. Higher leverage can lead to higher probability of bankruptcy and financial distress (Ross, Westerfield, and Jaffe, 2005). To estimate solvency, we use the debt-equity ratio (DER), the debt to total assets ratio (DTAR), and an equity multiplier (EM). Previous research indicates that Islamic banks are expected to be more solvent (less risky) than conventional banks (e.g. Samad, 2004; Kader and Asarpota, 2007; Moin, 2008).

Growth ratio represents the annual growth rate of bank shareholders' equity funds resulting from having very profitable reinvestment opportunities for retained earnings. Internal growth rate (IGR) is used in this study to estimate the bank's growth rate.

Basel III establishes higher and better quality capital standards through additional capital buffers, more restrictive capital definitions, higher risk-weighted assets (RWSs), and higher requirements for minimum capital ratios. Higher capital requirements will primarily help banks to use capital built up during boom times for periods of financial stress and hence reduce cyclicality in financial markets. As of 1 January 2019, banks will be required to meet the following new minimum requirements in relation to risk-weighted assets (RWAs): $4.5 \%$ common equity/RWAs, $6.0 \%$ Tier 1 capital/RWAs, and $8.0 \%$ total capital/RWAs. We begin by assessing the extent to which GCC banks, as a whole, comply with the new Basel III capital requirements. We then consider the extent to which the two groups of banks comply with these requirements. The banks-reported figures of common equity ratio, tier 1 
capital ratio, and capital adequacy ratio as disclosed in the 2011 annual reports are used. We are not aware of any study in the literature that has assessed the compliance of the GCC banking industry with Basel III capital standards.

Table 2 represents the calculations of all financial ratios used in this study.

Table 2

Calculations of Financial Ratios Employed in the Study

\begin{tabular}{|c|c|c|}
\hline Ratios & Calculation & Remarks \\
\hline \multicolumn{3}{|l|}{ Profitability Ratios } \\
\hline Return on Assets & ROA $=$ Net Profits after Tax $/$ Total Assets & $\begin{array}{l}\text { The higher the ratio, the better the performance } \\
\text { and assets utilization of the bank. }\end{array}$ \\
\hline Return on Equity & $\mathbf{R O E}=$ Net Profits after Tax / Owners' Equity & $\begin{array}{l}\text { The higher the ratio, the better the performance. } \\
\text { However, high ROE may be due to high financial } \\
\text { leverage. }\end{array}$ \\
\hline Net Interest Margin & $\begin{array}{l}\text { NIM = (Interest Income - Interest Expense) / } \\
\text { Average Earning Assets } \\
\text { NIM for Islamic Banks is profits from interest- } \\
\text { free lending contracts }\end{array}$ & $\begin{array}{l}\text { The higher the ratio, the better the profitability of } \\
\text { bank lending. }\end{array}$ \\
\hline Return on Deposits & ROD $=$ Net Profits After Tax / Total Deposits & $\begin{array}{l}\text { The higher the ratio, the better the bank in terms of } \\
\text { loans (for conventional banks) and in terms of } \\
\text { interest-free lending contracts (for Islamic banks). }\end{array}$ \\
\hline \multicolumn{3}{|l|}{ Liquidity Ratios } \\
\hline $\begin{array}{l}\text { Total Loans to } \\
\text { Deposits }\end{array}$ & $\begin{array}{l}\text { LD = Loans / Deposits } \\
\text { Here, Loans means the advances for the } \\
\text { conventional banks and financings (receivables) } \\
\text { for the Islamic Banks. }\end{array}$ & $\begin{array}{l}\text { Banks with higher LD are considered to have less } \\
\text { liquidity and more financial stress (risk). }\end{array}$ \\
\hline $\begin{array}{l}\text { Total Loans to Total } \\
\text { Assets }\end{array}$ & $\mathbf{L A}=$ Loans (or financings) $/$ Total Assets & The higher the ratio, the less liquid the bank. \\
\hline $\begin{array}{l}\text { Cash and Bank } \\
\text { Balances to Deposits }\end{array}$ & $\begin{aligned} \mathbf{C B B D}= & \text { Cash and balances at the central bank } \\
& \text { and other banks or financial institutions } \\
& \text { / Total Deposits }\end{aligned}$ & $\begin{array}{l}\text { The higher the ratio, the better the liquidity of the } \\
\text { bank. }\end{array}$ \\
\hline $\begin{array}{l}\text { Cash and Portfolio } \\
\text { Investment to Deposits }\end{array}$ & $\begin{array}{l}\text { CPID = Cash and Portfolio Investments / Total } \\
\text { Deposits }\end{array}$ & $\begin{array}{l}\text { The higher the ratio, the better the liquidity of the } \\
\text { bank. }\end{array}$ \\
\hline \multicolumn{3}{|l|}{ Efficiency Ratios } \\
\hline $\begin{array}{l}\text { Assets Utilization } \\
\text { (Turnover) }\end{array}$ & $\mathbf{A U}=$ Total Revenue $/$ Total Assets & $\begin{array}{l}\text { High AU means that the bank is efficiently using } \\
\text { its assets to their capacity. }\end{array}$ \\
\hline Operating Efficiency & $\begin{array}{l}\text { OE }=\text { Total Operating Expenses / Total } \\
\text { Operating Revenue }\end{array}$ & $\begin{array}{l}\text { The Lower OE the better. Low OE means that the } \\
\text { bank is efficiently generating more operating } \\
\text { income and controlling its operating expenses. }\end{array}$ \\
\hline \multicolumn{3}{|l|}{ Solvency Ratios } \\
\hline Debt-Equity Ratio & DE $=$ Total Debt / Owners' Equity & $\begin{array}{l}\text { The lower the ratio, the better the bank's capital to } \\
\text { absorb financial shocks (i.e. creditors default in } \\
\text { paying back their loans or decreases in asset } \\
\text { values). }\end{array}$ \\
\hline Debt to Total Assets & DTA $=$ Total Debt $/$ Total Assets & $\begin{array}{l}\text { High DTA indicates high debt or the ability of the } \\
\text { bank to obtain additional financing compared to } \\
\text { the equity financing. }\end{array}$ \\
\hline Equity Multiplier & $\mathbf{E M}=$ Total Assets / Owners' Equity & $\begin{array}{l}\text { High EM means that the bank has more debt to } \\
\text { convert into assets (and hence, greater risk). }\end{array}$ \\
\hline \multicolumn{3}{|l|}{ Other } \\
\hline Internal Growth Rate & $\begin{array}{l}\text { IGR }=\text { Retained Profits of year }{ }_{t} / \text { Owners' } \\
\text { Equity of year }{ }_{t-1}\end{array}$ & $\begin{array}{l}\text { The higher the ratio, the better the annual growth } \\
\text { rate of stockholders' equity fund resulting from } \\
\text { reinvesting the profits back. }\end{array}$ \\
\hline
\end{tabular}




\begin{tabular}{|l|l|l|}
\hline Basel III Capital Standards \\
\hline $\begin{array}{l}\text { Common } \\
\text { Equity/RWAs } \\
\text { (Tangible Common } \\
\text { Equity Ratio) }\end{array}$ & $\begin{array}{l}\text { Common Equity Ratio = (Common Shares }+ \\
\text { Retained Income - intangible assets - goodwill - } \\
\text { preferred stock equity) / RWAs }\end{array}$ & $\begin{array}{l}\text { The ratio determines how many losses a bank can } \\
\text { ake before shareholder equity is wiped out. The } \\
\text { conservative approach of this ratio has made it a } \\
\text { very risk free way for investors to evaluate worst } \\
\text { case scenarios of their investments. The higher the } \\
\text { ratio, the safer the bank. }\end{array}$ \\
\hline Tier 1 Capital/RWAs & $\begin{array}{l}\text { Tier I Capital Ratio = As the true figure for } \\
\text { Tier 1 capital ratio defined by Basel committee is is } \\
\text { may be considered subjective or challenging to } \\
\text { identify (e.g. deciding on the proper risk } \\
\text { weighting for assets), we use the bank-reported } \\
\text { figures as disclosed in the annual reports. }\end{array}$ & $\begin{array}{l}\text { The Tier 1 serves as a useful guide to revealing } \\
\text { whether bank can sustain further hits to its } \\
\text { balance sheet or needs to support its capital base, } \\
\text { but should be used together with other metrics to } \\
\text { get a more complete overview of a bank's health. } \\
\text { Basel also includes a measure of (e.g. Tier 2 } \\
\text { capital). The higher the ratio, the safer the bank. }\end{array}$ \\
\hline $\begin{array}{l}\text { Total Capital/RWAs } \\
\text { (Capital Adequacy } \\
\text { Ratio) }\end{array}$ & $\begin{array}{l}\text { Capital) / RWAs } \\
\text { We use the bank-reported figures as disclosed in } \\
\text { the annual reports. }\end{array}$ & $\begin{array}{l}\text { The higher the capital adequacy ratio, the safer the } \\
\text { bank. }\end{array}$ \\
\hline
\end{tabular}

This table shows the calculations of all financial ratios used in this study and provides some relevant remarks on these ratios. The study examines the financial performance of the banking industry in the GCC region using financial ratio analysis (FRA) in terms of profitability, liquidity, efficiency, solvency, growth, and compliance with Basel III's new quality capital standards.

\section{RESULTS}

Tables 3 and 4 present descriptive statistics for the comparative performance indicators of the pooled samples of conventional and Islamic banks, respectively. We do not report the results for the annual financial ratios over the nine-year period of the study because the overall conclusions drawn do not differ in a qualitative sense from those to be drawn from trends over time. The value of each ratio represents the average over the 2003-2011 study period. We examine the financial performance of the banking industry in the GCC region by using financial ratios in terms of profitability, liquidity, efficiency, solvency, and growth. We focus on evaluating indicators on the bank group as a whole (conventional and Islamic). Table 7 shows the results of a T-test for equality of means between both types of banks for each of the financial ratios used in this study.

The results indicate that the nine-year average Profitability ratios for Islamic banks are higher compared to conventional banks. On average, Islamic banks recorded higher ROA $(2.42 \%>1.72 \%)$, ROE $(13.74 \%>12.59 \%)$, NIM $(4.20 \%>3.55 \%)$, and ROD $(4.73 \%>3.02 \%)$ during $2003-2011$. Table 7 further shows that there is a statistically significant difference between the two types of banks as far as ROA, ROE, NIM, and ROD ratios are concerned (at least at the 5\% level). The annual profitability ratios (untabulated) indicate declining ROA, ROE, NIM, and ROD ratios for both types of the banks from 2008 onwards, as a result of the financial crisis that exploded worldwide during 2008 (i.e. higher provisioning charges). However, conventional banks report increased profitability during 2010 and 2011, indicating signs of recovery. This result is consistent with earlier findings in the literature, which indicates that profitability ratios in general are higher for Islamic banks (e.g. Karim and Ali, 1989; Rosly and Abu Baker, 2003; Kader and Asarpota, 2007; Olson and Zoubi, 2008). This superior profitability of Islamic banks is due mainly to the higher net income margin from financing activities resulting from their dependency on investment deposits as the main and cheaper source of funding compared to equity capital, money markets, and inter-bank activities in conventional banks. The higher profitability of Islamic banks may also imply better assets quality.

The results also reveal that the average Liquidity ratios for Islamic banks are higher compared to conventional banks. On average, Islamic banks recorded lower LD $(68.05 \%<72.04 \%)$ and LA $(50.82 \%<59.39 \%)$ and higher CBBD $(20.42 \%>18.64 \%)$ and CPID (38.19\% > 30.49\%) during 2003-2011. However, the p-values of liquidity ratios (Table 7) indicate that there is no statistically significant difference between liquidity ratios as far as LD, LA, CBBD, and CPID are concerned. Not surprisingly, the annual liquidity ratios (untabulated) indicate that Islamic banks significantly increased liquidity reserves during the 2005-2011 period compared to conventional banks in most GCC countries. This finding, however, contradicts the results taken from other studies that are based on an individual country-wise analysis (e.g. Rosly and Abu Baker, 2003; Kader and Asarpota, 2007). It can be argued that the better liquidity of Islamic banks may be due to shortages in Islamic money markets of the financial 
instruments available for long-term investments, as well as the limited financing that these banks can provide compared to conventional banks (i.e. from a Shariah compliance perspective). As a result, customer deposits generate little or no income for Islamic banks (e.g. Haron, 2004). In addition, we argue that GCC Islamic banks prudently hold more cash and near cash assets relative to deposits than conventional banks, in order to meet the risk of deposit withdrawals.

Considering banks' Efficiency, the average ratios for conventional banks are better compared to Islamic banks. On average, conventional banks recorded higher AU $(6.91 \%>4.70 \%)$ and lower OE $(35.88 \%<44.23 \%)$ during 2003-2011. Nevertheless, p-values of efficiency ratios indicate that there is no statistically significant difference between both types of banks as far as $\mathrm{AU}$ and $\mathrm{OE}$ ratios are concerned. This result is consistent with earlier findings in the literature indicating that conventional banks are expected to be more efficient than Islamic banks (e.g. Yudistira, 2004; Rosly and Abu Baker, 2003; Abdul-Majid et al., 2005; Drake et al., 2006; Olson and Zoubi, 2008; Moin, 2008). One interpretation of this result is that conventional banks are better than Islamic banks at generating income from diversified sources of revenues (i.e. loans or earning assets in addition to other noninterest income). However, Islamic banks on the macro level are less efficient in managing their overall costs (i.e. other operating and non-operating expenses). Islamic banks in the GCC region report a higher growth rate of operating expenses (i.e. at a faster rate than the growth rate of operating income) compared to conventional banks (e.g. Siraj and Pillai, 2012). Our earlier finding on the superior profitability of Islamic Banks is mainly due to lower costs of funds and better asset quality compared to conventional banks.

The average Solvency ratios indicate that Islamic banks are more solvent (less risky) than conventional banks. On average, Islamic banks recorded lower DE $(596.50 \%<693.04 \%)$, DTA $(83.46 \%<87.74 \%)$, and EM $(6.05<8.16)$ during $2003-2011$. The p-values of solvency ratios indicate that there is a statistically significant difference between the two types of banks, as far as DE, DTA, and EM ratios are concerned (at least at the 5\% level or better). This result is consistent with earlier findings in the literature (e.g. Samad, 2004; Kader and Asarpota, 2007; Moin, 2008). Conventional banks depend more on debts and liabilities than Islamic banks, in which more equity funds are used towards total assets. Hence, Islamic banks are less leveraged (or more solvent). Samad (2004) argues that Islamic banks are more cautious about their credit advancement, so they are more conservative than conventional banks in selecting investments in which their long-term loans are a small percentage of the total.

The average Internal Growth Rate (IGR) of Islamic banks is higher than that of conventional banks during $2003-2011(11.15 \%>7.88 \%)$. The difference between the IGR of both types of banks is statistically significant (pvalue $=0.001$ ). This result reveals that the nine-year average internal growth rate of stockholders' equity funds resulting from reinvesting profits is higher in Islamic banks. We believe that these reinvested funds provide a better cushion (higher equity buffer) against shocks, but they might negatively affect the profitability of the bank, as more funds than needed are booked under equity.

Tables 5 and 6 present descriptive statistics for the comparative Basel III capital requirements of the pooled samples. The results indicate that GCC banks, as a whole, appear to be largely sufficiently capitalized for Basel III. Capital adequacy ratios (CAR) for the majority of GCC banks in 2011 comfortably satisfy the enhanced capital requirements of Basel III. The average ratio for the region is $16.7 \%$. The minimum CAR was recently lifted to $12.1 \%$ in Oman (untabulated). The results also indicate that Islamic banks have, on average, a noticeably higher CAR compared to the conventional banking sector $(19.92 \%>14.47 \%)$. Moreover, nearly all of banks' capital is actually Tier 1 capital. Hence, the new Tier 1 requirement of $6 \%$ (or $8.5 \%$ including buffers) is securely met (i.e. an average of $16.61 \%$ and $10.86 \%$ for Islamic and conventional banks, respectively). Table 7 further shows that there is a statistically significant difference between the two types of banks as far as Tier 1 Capital Ratio and CAR are concerned (at least at the 5\% level or better). The findings may suggest that Basel III's capital requirements will not require GCC banks to go through any additional forms of capitalization, especially Islamic banks. GCC banks are well positioned to absorb higher provisions and impairment charges given the higher capital adequacy ratios reported by most. It can also be argued that Basel III's capital standards are unlikely to add materially to the existing challenges faced by Islamic banks. However, they will lead the agenda of many conventional banks, particularly the more speculative and leveraged.

With regard to the impact of the global financial crisis on both types of banks, the annual results (untabulated) indicate that Islamic banks performed better during the period 2006-2009. Islamic banks had higher 
capitalization, higher liquidity reserves, and also maintained stronger growth compared to conventional banks in almost all GCC countries.

Table 3

Descriptive Statistics of "Conventional Banks" Financial Ratios (2003-2011)

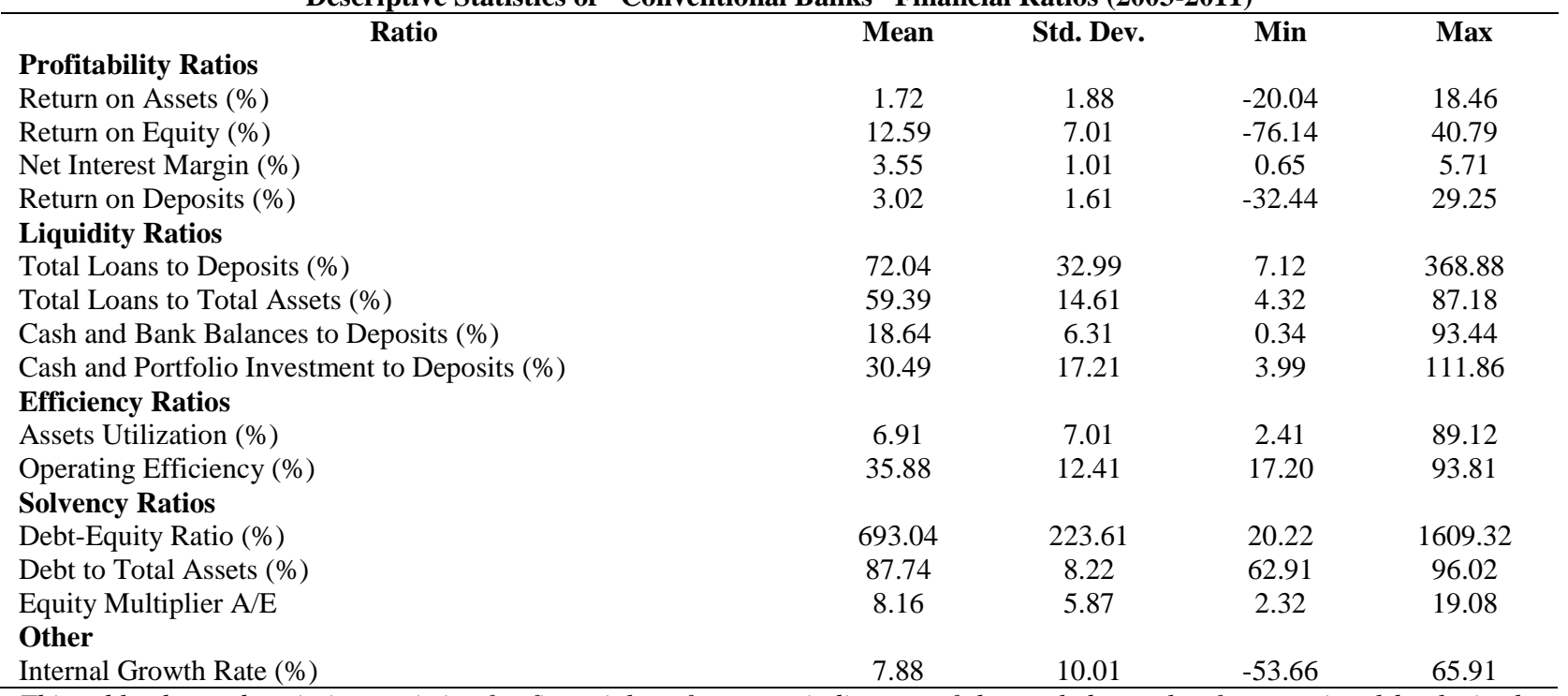

This table shows descriptive statistics for financial performance indicators of the pooled sample of conventional banks in the GCC region. The value of each ratio represents the average over the study period 2003-2011. The study examines the financial performance of the banking industry in the GCC region using financial ratios in terms of profitability, liquidity, efficiency, solvency, growth, and compliance with Basel III's new quality capital standards. Descriptive statistics for conventional banks' compliance with Basel III's new quality capital standards are presented separately in Table 5.

Table 4

Descriptive Statistics of "Islamic Banks" Financial Ratios (2003-2011)

\begin{tabular}{|c|c|c|c|c|}
\hline Ratio & Mean & Std. Dev. & Min & Max \\
\hline \multicolumn{5}{|l|}{ Profitability Ratios } \\
\hline Return on Assets (\%) & 2.42 & 2.88 & -12.82 & 32.4 \\
\hline Return on Equity (\%) & 13.74 & 16.56 & -131.43 & 72.33 \\
\hline Net Interest Margin (\%) & 4.20 & $1.21 \%$ & -0.73 & 7.64 \\
\hline Return on Deposits (\%) & 4.73 & 2.09 & -41.99 & 36.56 \\
\hline \multicolumn{5}{|l|}{ Liquidity Ratios } \\
\hline Total Loans to Deposits (\%) & 68.05 & 29.14 & 22.15 & 336.14 \\
\hline Total Loans to Total Assets (\%) & 50.82 & 13.45 & 11.44 & 92.16 \\
\hline Cash and Bank Balances to Deposits (\%) & 20.42 & 9.52 & 2.15 & 76.71 \\
\hline Cash and Portfolio Investment to Deposits (\%) & 38.19 & 12.24 & 5.91 & 132.43 \\
\hline \multicolumn{5}{|l|}{ Efficiency Ratios } \\
\hline Assets Utilization (\%) & 4.70 & 3.86 & 1.22 & 94.33 \\
\hline Operating Efficiency (\%) & 44.23 & 11.53 & 19.76 & 91.80 \\
\hline \multicolumn{5}{|l|}{ Solvency Ratios } \\
\hline Debt-Equity Ratio (\%) & 569.50 & 288.33 & 8.12 & 1233.07 \\
\hline Debt to Total Assets (\%) & 83.46 & 17.66 & 63.71 & 97.52 \\
\hline Equity Multiplier A/E & 6.05 & 5.86 & 2.12 & 14.17 \\
\hline \multicolumn{5}{|l|}{ Other } \\
\hline Internal Growth Rate (\%) & 11.15 & 14.21 & -14.65 & 136.77 \\
\hline
\end{tabular}


Table 5

Descriptive Statistics of "Conventional Banks" Basel III Capital Standards -2011

\begin{tabular}{lcccc}
\hline \multicolumn{1}{c}{ Ratio } & Mean & Std. Dev. & Min & Max \\
Basel III Capital Standards - 2011 & & & & \\
Common Equity Ratio (\%) & 7.54 & 2.41 & 6.03 & 13.59 \\
Tier I Capital Ratio (\%) & 10.86 & 4.34 & 8.58 & 16.11 \\
Capital Adequacy Ratio (\%) & 14.47 & 5.11 & 12.10 & 19.38 \\
\hline
\end{tabular}

This table shows descriptive statistics for compliance with Basel III's new quality capital standards of the pooled sample of conventional banks in the GCC region. The value of each ratio represents the average over the study period 2003-2011.

Table 6

Descriptive Statistics of "Islamic Banks" Basel III Capital Standards -2011



Table 7

Differences between the Means of Conventional and Islamic Banks' Financial Ratios (2003-2011) - "t-test"

\begin{tabular}{|c|c|c|c|c|}
\hline Ratio & $\begin{array}{c}\text { Conventional Banks } \\
\text { (Mean) }\end{array}$ & $\begin{array}{l}\text { Islamic Banks } \\
\text { (Mean) }\end{array}$ & $t$-test & $p$-value \\
\hline \multicolumn{5}{|l|}{ Profitability Ratios } \\
\hline Return on Assets (\%) & 1.72 & 2.42 & 2.368 & $0.023^{*}$ \\
\hline Return on Equity (\%) & 12.59 & 13.74 & 1.820 & $0.042 *$ \\
\hline Net Interest Margin (\%) & 3.55 & 4.20 & 2.669 & $0.011 *$ \\
\hline Return on Deposits (\%) & 3.02 & 4.73 & 2. 841 & $0.019 *$ \\
\hline \multicolumn{5}{|l|}{ Liquidity Ratios } \\
\hline Total Loans to Deposits (\%) & 72.04 & 68.05 & 1.251 & 0.073 \\
\hline Total Loans to Total Assets (\%) & 59.39 & 50.82 & 0.901 & 0.522 \\
\hline Cash and Bank Balances to Deposits (\%) & 18.64 & 20.42 & 1.066 & 0.288 \\
\hline Cash and Portfolio Investment to Deposits (\%) & 30.49 & 38.19 & 0.765 & 0.871 \\
\hline \multicolumn{5}{|l|}{ Efficiency Ratios } \\
\hline Assets Utilization (\%) & 6.91 & 4.70 & 1.033 & 0.117 \\
\hline Operating Efficiency (\%) & 35.88 & 44.23 & 1.108 & 0.096 \\
\hline \multicolumn{5}{|l|}{ Solvency Ratios } \\
\hline Debt-Equity Ratio (\%) & 693.04 & 569.50 & 2.840 & $0.027 *$ \\
\hline Debt to Total Assets (\%) & 87.74 & 83.46 & 2.679 & $0.030 *$ \\
\hline Equity Multiplier A/E & 8.16 & 6.05 & 3.741 & $0.001 * *$ \\
\hline \multicolumn{5}{|l|}{ Other } \\
\hline Internal Growth Rate (\%) & 7.88 & 11.15 & 3.644 & $0.001 * *$ \\
\hline \multicolumn{5}{|l|}{ Basel III Capital Standards } \\
\hline Common Equity Ratio (\%) & 7.54 & 11.65 & 1.909 & $0.038 *$ \\
\hline Tier I Capital Ratio (\%) & 10.86 & 16.61 & 2.891 & $0.010 * *$ \\
\hline Capital Adequacy Ratio (\%) & 14.47 & 19.92 & 3.970 & $0.000 * *$ \\
\hline
\end{tabular}

\section{SUMMARY AND CONCLUSIONS}

The main objective of this study was to assess the financial performance of a full set of Islamic and conventional banks across various GCC countries using ratio analysis, and to answer the question as to which banking system better complies with Basel III's new requirements for higher and better quality capital. This study is 
the first to consider the extent to which Islamic vs. conventional banks in the GCC comply in this respect. The study uses bank-level data for 75 (55 conventional and 20 Islamic) banks in the GCC region over the period 2003 to 2011. An individual country-wise analysis is not intended here. We focus on evaluating the indicators on the bank group as a whole (conventional and Islamic). Both Islamic banks and conventional banks are placed on an equal footing under ratio measures, irrespective of the bank's size.

The choice of the GCC zone is justified by the fact that these countries, which are at the heart of the Islamic world, are experiencing a significant increase in the number of Islamic banks, a high growth rate in Shariahcompliant global financial assets, and sound financial health. Furthermore, Islamic financial institutions in the GCC region are taking an increasingly global perspective. The motivation for this study is that a comprehensive sample of data available in the GCC needs to be examined before any substantive conclusions can be reached about the relative performances of Islamic and conventional banks. Hence, this study is a commentary on the financial performance and quality capital of these institutions currently operating in the GCC region.

The results reveal that Islamic banks are, on average, less efficient but more profitable, more liquid, and more solvent (less risky), and enjoyed higher internal growth than conventional banks in the GCC region during 2003-2011. The results indicate that there are statistically significant differences between the two types of banks as far as profitability, solvency, and internal growth rate ratios are concerned. However, there are no statistically significant differences in liquidity and efficiency. The results also indicate that GCC banks, as a whole, appear to be largely sufficiently capitalized for Basel III. GCC banks are also well positioned to absorb higher provisions and impairment charges, given the higher capital adequacy ratios reported by most. The common equity ratio, Tier 1 capital ratio and capital adequacy ratios (CAR) for the majority of GCC banks in 2011 comfortably satisfy the enhanced capital requirements of Basel III. The results show that Islamic banks have, on average, noticeably higher (and significantly different) capital ratios compared to the conventional banking system. With regard to the impact of the global financial crisis on both types of the banks, the results indicate that Islamic banks performed better during 2006-2009 as a result of higher capitalization and higher liquidity reserves, and the fact that they also maintained stronger growth in almost GCC countries.

The analysis is limited in several ways. First, some published annual reports from the GCC banks do not contain adequate details to allow for a comprehensive and in-depth financial analysis. They also do not use a standard format for all GCC banks. A second limitation is that both Islamic banks and conventional banks are placed on an equal footing under financial ratio measures, irrespective of the bank's size. Third, the scope of the study is limited to focusing on evaluating indicators on the bank group as a whole (conventional and Islamic). An individual country-wise analysis is not recognized here either, but although the study has clear limitations, it is hoped that it makes useful contribution to the financial performance literature.

Future studies could examine the effects of bank size (i.e. small, medium, and large) on the determinants of the financial performance and quality capital of Islamic and conventional banks in the GCC region. In addition, future research in the area might look at GCC country-wise differences in financial performance and quality capital using disaggregated data by country, while another study might investigate the issue of financial performance and quality capital in other non-GCC and/or non-Muslim countries. The use of questionnaires and interview methodologies could also be adopted for research in the area of the financial performance and quality capital of Islamic vs. conventional banks. Such approaches could provide more valuable insights into the management perceptions of financial performance and quality capital determinants, and establish a better understanding of financial report users' responses. Also, the combination of quantitative and qualitative approaches could complement each other in searching for financial performance.

\section{AUTHOR INFORMATION}

Osama M. Al-Hares, Accounting Department—Gulf University for Science and Technology (GUST), Kuwait. He received his $\mathrm{PhD}$ in Accounting from Manchester Business School, U.K. His research appears in journals such as Journal of International Financial Management and Accounting (JIFMA), Global Finance Journal, International Journal of Economics and Finance (IJEF), Journal of Applied Business Research (JABR), and Journal of Modern Accounting and Auditing (JMAA). He can be reached at Gulf University for Science and Technology (GUST), P. O. Box 7207, Hawally 32093 Kuwait, E-mail: AlHares.O@ gust.edu.kw (Corresponding author) 
Naser M. AbuGhazaleh, Accounting Department—Gulf University for Science and Technology (GUST), Kuwait. $\mathrm{He}$ received his $\mathrm{PhD}$ in Accounting from Aberdeen University, U.K. His research appears in journals such as Journal of International Financial Management and Accounting (JIFMA), Global Finance Journal, International Journal of Economics and Finance (IJEF), Journal of Applied Business Research (JABR), and Advances in International Accounting (AIIA). He can be reached at Gulf University for Science and Technology (GUST), P. O. Box 7207, Hawally 32093 Kuwait, E-mail: Abughazaleh.n@gust.edu.kw

Ahmed Mohamed El-Galfy, Accounting Department-Gulf University for Science and Technology (GUST), Kuwait- currently on leave from Cairo University. He received his PhD in Accounting from Manchester University, U.K. His research appears in journals such as Journal of Empirical Finance, Journal of International Finance and Economics, European Journal of Management, International Journal of Business Research, and Journal of Applied Business Research. He can be reached at Gulf University for Science and Technology (GUST), P. O. Box 7207, Hawally 32093 Kuwait, E-mail: Galfy.A@gust.edu.kw

\section{REFERENCES}

1. AAOIFI, 2010. Accounting, Auditing and Governance Standards for Islamic Financial Institutions (Accounting and Auditing Organization for Islamic Financial Institutions), Bahrain.

2. Abdel-Haq, M. K., 1989. Islamic Development Bank: An Analytical Study. (Working Paper), Yarmouk University, Jordan.

3. Abdul-Majid M., Mohammed Nor, N.G., Said, F.F., 2005. Efficiency of Islamic Banks in Malaysia. In: Iqbal, M. / Ahmad, A. (Eds), Islamic Finance and Economic Development. Palgrave Macmillan, New York, pp. 94-115.

4. Ahmed, A. M., Khababa, N., 1999. Performance of the Banking Sector in Saudi Arabia. Journal of Financial Management and Analysis, 12, pp. 30-36.

5. Alam, M. N., 2003. Micro Credit Through 'Bai-Mujjal’ Mode of Islamic Banking Financing System. Conference of SANABEL. Canada.

6. Al-Gzaairi, A., 1979. The Muslim Route. Al-Klyat Al-Azhariah Bookshop, Cairo, Egypt.

7. Ali, S. S., 2004. Islamic Modes of Finance and Associated Liquidity Risks, Monetary Sector in Iran: Structure, Performance and Challenging Issues. (Working Paper), Tehran, Iran.

8. Al-Jindee, 1986. Murabaha Contract Between Islamic Figh and Bank Dealing. Dar Al-Nahdah Al-Arabia, Cairo, Egypt.

9. Al-Omar, F., and Abdel-Haq, M., 1996. Islamic Banking: Theory, Practice and Challenges. Zed Books Ltd., UK.

10. Al-Qaradawi, Y., 1987. Murabaha Purchase Order as it Works in Islamic Banks. Library of Wahbhi, Cairo, Egypt.

11. Al-Tamimi, H. A., and Al-Amiri, A., 2003. Analysing Service Quality in the UAE Islamic banks. Journal of Financial Services Marketing, 8 (2), pp.119-132.

12. Ariff, M., 1988. Islamic Banking. Asian-Pacific Economic Literature, 2 (2), September: pp. 46-62.

13. Bashier, B. A., 1983. Portfolio Management of Islamic Banks: A Certainty Approach. Journal of Banking and Finance, 7, pp. 339-354.

14. Bashir, A., 2003. Determinants of Profitability in Islamic Banks: Some Evidence from the Middle East. Journal of Islamic Economics Studies, 11 (1), pp. 31-53.

15. Beck, T., Demirguc-Kunt, A., and Merrouche, O., 2010. Islamic Vs. Conventional Banking Business Model. World Bank - Efficiency and Stability Policy Research Working Paper, 5446, October.

16. Chapra, M. U., 1998. The Major Modes of Islamic Finance, Islamic Economics, Banking and Finance (Working Paper), Leicester, U.K.).

17. Cihak, M., and Hesse, H., 2010. Islamic Banks and Financial Stability: An Empirical Analysis, Journal of Financial Services Research, 38 (2\&3), pp. 95-113.

18. Demirgue-Kunt, A., and Hizinga, H., 1999. Determinants of Commercial Bank Interest Margins and Profitability: Some International Evidence. The World Bank Economic Review, 13, pp. 379-408.

19. Drake, L., Hall, M.J.B., and Simper, R., 2006. The Impact of Macroeconomic and Regulatory Factors on Bank Efficiency: A Non-Parametric Analysis of Hong Kong's Banking System. Journal of Banking and Finance, 30, pp. 1443-1446. 
20. El-Galfy, A., 1991. The Bases Measurement of Murabaha in Islamic Banks, Cairo University, Egypt.

21. Essayyad, M., and Madani, H., 2003. Investigating Bank Structure of an Open Petroleum Economy: The Case of Saudi Arabia. Managerial Finance, 29, pp. 73-92.

22. Hamdan, C., 2009. Banking on Islam: A Technology Perspective. Islamic Finance News, 6 (19).

23. Haron, S., 2000. A Comparative Study of Islamic Banking Practices, Islamic Economic, 10 (1), January: pp. 1-31.

24. Haron, S., 2004. Determinants of Islamic Bank Profitability. Global Journal of Finance and Economics, 1 (1), pp.11-33.

25. Hasan, M., and Dridi, J., 2010. The Effects of the Global Crisis on Islamic and Conventional Banks: A Comparative Study; IMF Working Paper, WP/10/201.

26. Islam, M., 2003. Development and Performance of Domestic and Foreign Banks in the GCC Countries. Managerial Finance, 29, pp.42-72.

27. Kader, J.M., Asarpota, A.K., and Al-Maghaireh, A., 2007. Comparative Financial Performance of Islamic Banks vis-à-vis Conventional Banks in the UAE. Chancellor's Undergraduate Research Award, University Al-Ain, U.A.E, pp. 38-52.

28. Karim, R., and Ali, A., 1989. Determinants of the Financial Strategy of Islamic Banks. Journal of Business Finance and Accounting, 16 (2), pp.193-212.

29. Khan, M.S., 1986. Islamic Interest-Free Banking: A Theoretical Analysis. IMF Staff Papers DM/85754.

30. Moin, M. S., 2008. Performance of Islamic Banking and Conventional Banking in Pakistan: A Comparative Study, Finance (University of Skovde).

31. Olson, D., and Zoubi, T., 2008. Using Accounting Ratios to Distinguish Between Islamic and Conventional Banks in the GCC Region. The International Journal of Accounting, 43, pp. 45-65.

32. Parashar S.P., and Venkatesh, J., 2010. How Did Islamic Banks Do During Global Financial Crisis? Banks and Bank Systems, 5 (4), pp. 54-62.

33. Pomeranz, F., 1997. The Accounting and Auditing Organization for Islamic Financial Institutions, Journal of International Accounting Auditing and Taxation, 6 (1), June, pp. 1-7.

34. Ramanathan, R., 2007. Performance of Banks in Countries of the Gulf Cooperation Council. International Journal of Productivity and Performance Management, 56 (2), pp. 137-154.

35. Rosly, S. A., Abu Bakar, M. A., 2003. Performance of Islamic and Mainstream Banks in Malaysia. International Journal of Social Economics, 30 (12), pp. 1249-1265.

36. Ross, S.A., Westerfield, R.W., and Jaffe, J.F., 2005. Corporate Finance. $7^{\text {th }}$ Edition, McGraw-Hill Irwin.

37. Samad, A., 2004. Performance of Interest Free Islamic Banks vis-à-vis Interest-Based Conventional Banks of Bahrain. Journal of Economics and Management, 12 (2), pp. 1-25.

38. Samad, A., and Kabir, H., 2000. The performance of Malaysian Islamic Bank During 1984-1997: An Exploratory Study. Thoughts on Economics, 10 (1\&2), pp. 7-26.

39. Schaik, D., 2001. Islamic Banking. The Arab Bank Review, 3 (1), April, pp. 45-52.

40. Shehatah, S.I., 1987. The Accounting Theory in the Islamic View. Al-Zahrai for Arabic Information, Cairo, Egypt.

41. Siddiqui, M. N., 1986. Islamic Banking: Theory and Practice. (Working Paper).

42. Siraj, K., and Pillai, S., 2012. Comparative Study on Performance of Islamic Banks and Conventional Banks in GCC Region. Journal of Applied Finance and Banking, 2 (3), pp. 123-161.

43. Suleiman, N. M., 2000. Corporate Governance in Islamic Bank. Islamic Banking, 1 (1), January: pp. 99 116.

44. Taylor, J. M., 2003. Islamic Banking. American Business law Journal, 40, pp. 386-416.

45. Turen, S., 1996. Performance and Risk Analysis of Islamic Banks: The Case of Bahrain Islamic Bank. Journal of King Abdulaziz University: Islamic Economics [Online], (8), pp. 3-14. Available from: http://www.kantakji.com/fiqh/Files/Banks/7001.pdf.

46. Wilson, R., 1987. Financial Development of the Arab Gulf: The Eastern Bank Experience, 1917-50. Business History, 29, pp. 178-198.

47. Wilson, R., 2009. Why Islamic Banking is Successful? Islamic Banks are Unscathed Despite of Financial Crisis. [Online], Available from: http://www.isdbforum.org/Subjects/Islam_and_the_Financial_Crisis/rwilson.pdf.

48. Yudistira, D., 2004. Efficiency in Islamic Banking: An Empirical Analysis of 18 Banks. Islamic Economic Studies, 12 (1), pp. 1-19. 